\title{
New Lithostratigraphic Units in the Croatian Offshore and Their Definition in the $« R »$ Programming Language
}

The Mining-Geology-Petroleum Engineering Bulletin UDC: 551.3 .051

DOI: 10.17794/rgn.2015.2.4

Professional paper

\author{
Marijan Šapina ${ }^{1,+}$; Marko Vekic $\mathbf{c}^{2,+}$ \\ ${ }^{1}$ Pavićeva 93, 31400 Đakovo \\ ${ }^{2}$ Splitska 23/2, 20350 Metković \\ ${ }^{+}$bachelor of petroleum engineering, active graduate student at Faculty of Mining, Geology and Petroleum Engineering, University of Zagreb
}

\begin{abstract}
New lithostratigraphic units in the Croatian offshore have been recently proposed, and are now used, especially in the Pleistocene and Holocene sediments. Two new formations in the Croatian part of the Northern Adriatic have been previously named (Istra and Ivana), as well as recently three new lithostratigraphic members inside the Ivana Formation. In addition, a name change of the Susak Formation has been proposed. Furthermore, in the Southern Dalmatia shallow offshore (i.e., palaeosediments of the Neretva River), the new Neretva Channel Formation has been recently named. It is divided into the Neretva Sands and the Mali Ston Bay Member. Due to the often descriptive task of the definition of the lithostratigraphic units, here the simplification of the task is made possible by the algorithm and the source code which are based on a sufficient number of measured porosity values in a vertical of a lithological unit or a depositional sequence. The algorithm directly defines the procedure for testing the hypothesis of the normal distribution of porosity values, and the code does it numerically and graphically. The normality test is performed with the Shapiro-Wilk test. Depending on the results of the hypothesis test (normal distribution of the measured values), it is simply evaluated if it is a homogeneous, permeable or non-permeable, or a heterogeneous lithostratigraphic unit, that always can be distinguished from the top and the base. Based on the result, and familiarity with the geographical location of the sample, the unit is easily named following the rules of lithostratigraphic nomenclature.
\end{abstract}

\section{Keywords}

Adriatic Sea, Cenozoic, lithostratigraphy, null hypothesis, Shapiro-Wilk test.

\section{Introduction}

The Republic of Croatia territory includes more than $54000 \mathrm{~km}^{2}$ of the Adriatic Sea. Adriatic offshore presents a mosaic of geological areas that are covered and presented in this thesis, with the special turn on lithostratigraphy, classification of the lithostratigraphic units, their description, naming and correlation with the purpose of determining their relation in space and time. To determine the lithostratigraphic units, rock properties are also used, such as porosity, permeability, rock saturation and hydrocarbon potential. Therefore, potential oil and gas areas are defined and classified. The definition of lithostratigraphic units is standardized by the procedure based on the usage of the „ $R$ “ programming language, programming the environment for the statistics, analysis of data and graphical representation. Within the very program there is a content of approx. 20 standardized packages (for matrixes, graphics, linear models, etc.), from which some are used to make algorithms, such as "ggplot2", "moments", and others. 


\section{Geographical location of the explored area}

The Adriatic Sea is an epicontinental, closed sea and a part of the Mediterranean. It was formed on the Adriatic microplate in the Late Miocene and it was bathymetrically formed during the Holocene after the Flandrian transgression (e.g., Colantoni et al., 1979; Fairbanks, 1989; Stanley, 1995). Nowadays, the Adriatic Sea covers the part of the Adriatic Basin which consists of the inner, terrestrial part of the river Po depression. It is surrounded by Southern Limestone Alps, the Dinarides and the Apennines (e.g., Balić \& Malvić, 2013). The Adriatic Basin is divided on particular depressions of different ages regarding their beginning of creation (Prelogović \& Kranjec, 1983). Three depressions are formed in the Miocene: Dugi otok, South Adriatic-Albania and Molise. Afterwards, in the Pliocene, sinking of sea basin bottom caused the forming of other depressions: Venetto, Po, Marche-Abruzzi, Middle Adriatic, Bradano and Adriatic-Ionian (Figure 1).

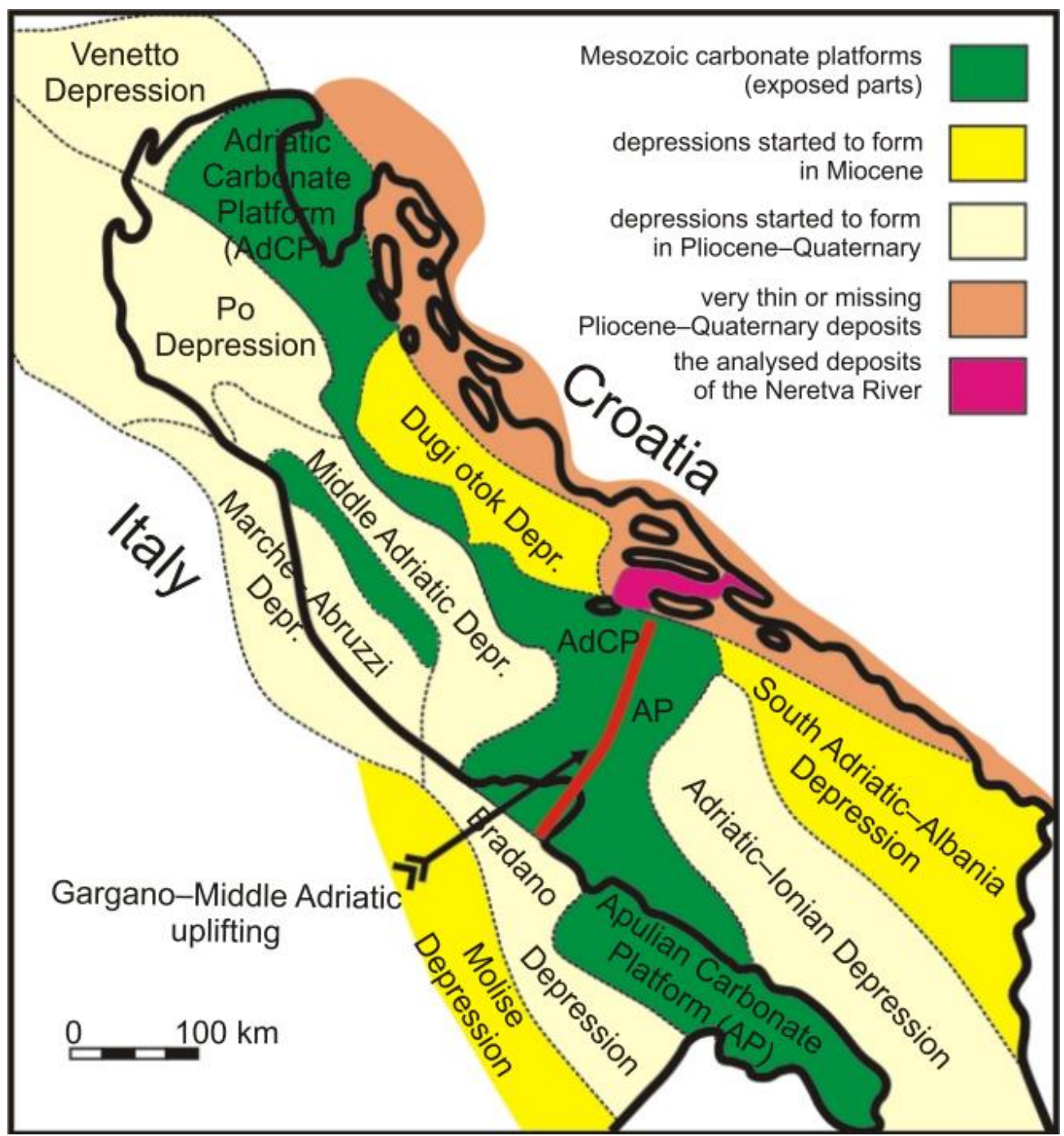

Figure 1: Miocene and Pliocene-Quaternary depressions in the Adriatic Basin (modified from Velić \& Malvić, 2ol1; Balić

\& Malvić, 2013)

The Croatian part includes the entire Dugi otok Depression, eastern parts of the Po and Middle Adriatic Depressions and the northern part of the Southern Adriatic-Albania Depression. The Adriatic Carbonate Platform sediments, the oldest drilled deposits in the Croatian offshore are mostly located in Croatia. They also extend through Italy, Slovenia, Bosnia and Herzegovina, Montenegro and Albania (Figure 2). 


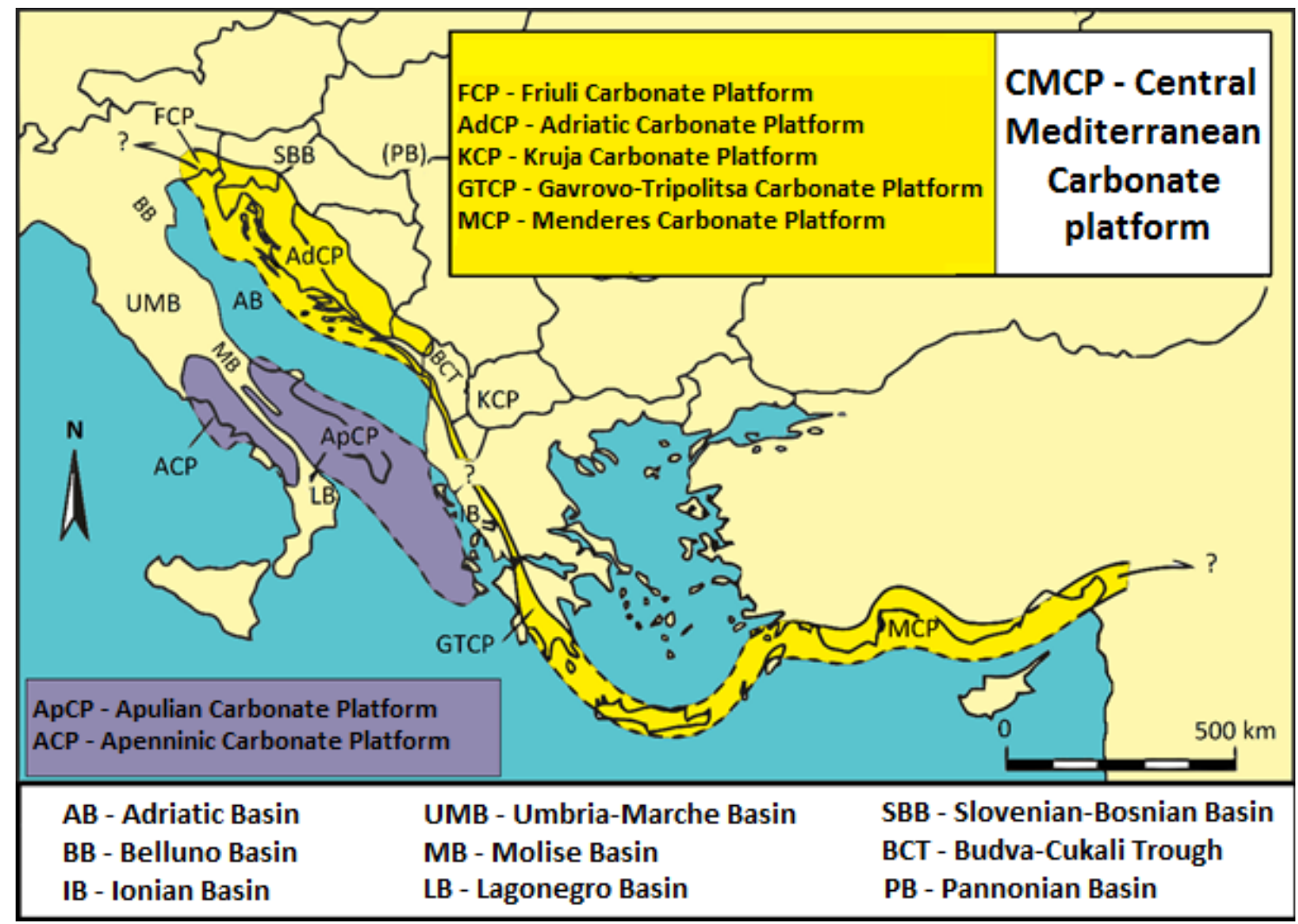

Figure 2: Map of Carbonate platforms in the Middle Mediterranean (modified from Vlahović et al., 2005)

These sediments comprise a major part of the entire carbonate succession of the Croatian offshore and the Croatian Karst Dinarides with its thickness exceeding more than $8000 \mathrm{~m}$ in some places (Tišljar et al. 20o2; Velić et al. 2002) with the stratigraphic span from Middle Permian to Eocene (Velić et al., 20o2). It extends from the Northeast shore of the Adriatic Sea to the Apulia Carbonate Platform in the South, a bit farther from the Apennine platform in the South/Southwest and the Pannonian Basin system which Dinarides, as a part of the Adriatic Carbonate Platform, border with in the Northeast (Figure 2).

\section{Previous explorations and research methods}

The Croatian area of the Adriatic Sea was explored mostly by the national company INA Plc. Between 1982 and 1989 research has been made in an area of $17000 \mathrm{~km}^{2}$ in cooperation with foreign partners such as AGIP, Chevron, Texaco and Hispanoil, wherein INA- Naftaplin covered 51\% of total concessions (Velić, 2007). A total of 13 wells have been drilled. A non-commercial amount of gas has been found in 2 wells, 1 well had a trace of oil, and 10 wells had no carbohydrate potential. From the beginning of exploratory drilling in 1970, until 2000, 116 exploratory and 12 development wells have been made, as well as $75000 \mathrm{~km}^{2}$ of seismic profiles (Velić, 2007). It is generally accepted that offshore and island area from the West coast of Istra to Prevlaka present a perspective area for oil and gas discovery, especially in the area where the anhydrite-carbonate rock complex of Mesozoic age has been confirmed (Spaić, 2012). An assumption got more probable after a very deep (6041 $\mathrm{m})$ exploratory well Brač-1ß on the island Brač was drilled, which confirmed that these rocks make a closed oil and gas geological system which has very large pressure. Anhydrite-carbonate complex of potential bed rocks has been confirmed in the area from Rab island, to Ravni kotari and the Southern Adriatic islands, and is assumed to be beneath a (part) of the Dinaric Alps. That complex has an area of $18000 \mathrm{~km}^{2}$, and most significant oil and gas reserves have been confirmed inside it (Spaić, 2012). Anhydrites occur in the Lower Cretaceous deposits in wells drilled in this area. Lower Cretaceous anhydrites are represented by typical sabkha cycles (Tišljar, 1984), composed of members A, B and C, where member A is composed of kerogenous ostracod wackestones/mudstones deposited 
in a subtidal-lagoon, member B of homogenous and stromatolitic intertidal/ supratidal early-diagenetic dolomite and member $C$ nodular sabkha anhydrite (Tišljar et al., 20o2).

During the early 8o's, several gas fields of Pliocene-Pleistocene age which later gained a significant production of carbohydrates have been discovered. From north to south, commercial gas fields that have been discovered by development wells are: Izabela, Ivana, Ika, Anamarija, Marica and Katarina.

Gas fields are found in unconsolidated or weakly consolidated sands of Pleistocene age that are deposited in Po depression (Malvić et al., 2011). Gas from these fields is biogenic, and is classified as pure methane with a 1.6\% nitrogen share as in the Ivana Field (e.g., Đureković et al., 1998).

\subsection{Present-day lithostratigraphy in the Croatian part of the Adriatic Sea}

By the North American Stratigraphic Code (North American Commission On Stratigraphic Nomenclature, 2005), formal lithostratigraphical units (from the largest to the smallest) are: supergroup, group, formation, member and bed.

A supergroup is a formal assemblage of related or superposed groups, or of groups and formations which have mutual important lithological properties. Supergroups should be named only where their recognition serves a clear purpose, because it is very rarely possible to correlate such a sequence of lithological units.

A group is the lithostratigraphic unit that may consist entirely of named formations, or alternatively, need not be composed entirely of named formations. Groups are defined to express the natural relations of associated formations. They are useful in smallscale mapping and regional stratigraphic analysis.

A formation is the fundamental unit in lithostratigraphic classification (Figure 3). A formation is a body of rock identified by lithic characteristics and a stratigraphic position; it is prevailingly but not necessarily tabular and is visible at the Earth's surface or traceable in the subsurface.

A member is the formal lithostratigraphic unit next in rank below a formation and is always a part of some formation. It is recognized as a named entity within a formation because it possesses characteristics distinguishing it from adjacent parts of the formation.

A bed, or beds, is the smallest formal lithostratigraphic unit of sedimentary rocks. Only important beds are named, such as oil sands or other beds of economic importance. A key or marker bed is a thin bed of distinctive rock that is widely distributed. Such beds may be named, but usually are considered informal units. Individual key beds may be traced beyond the lateral limits of a particular formal unit. 


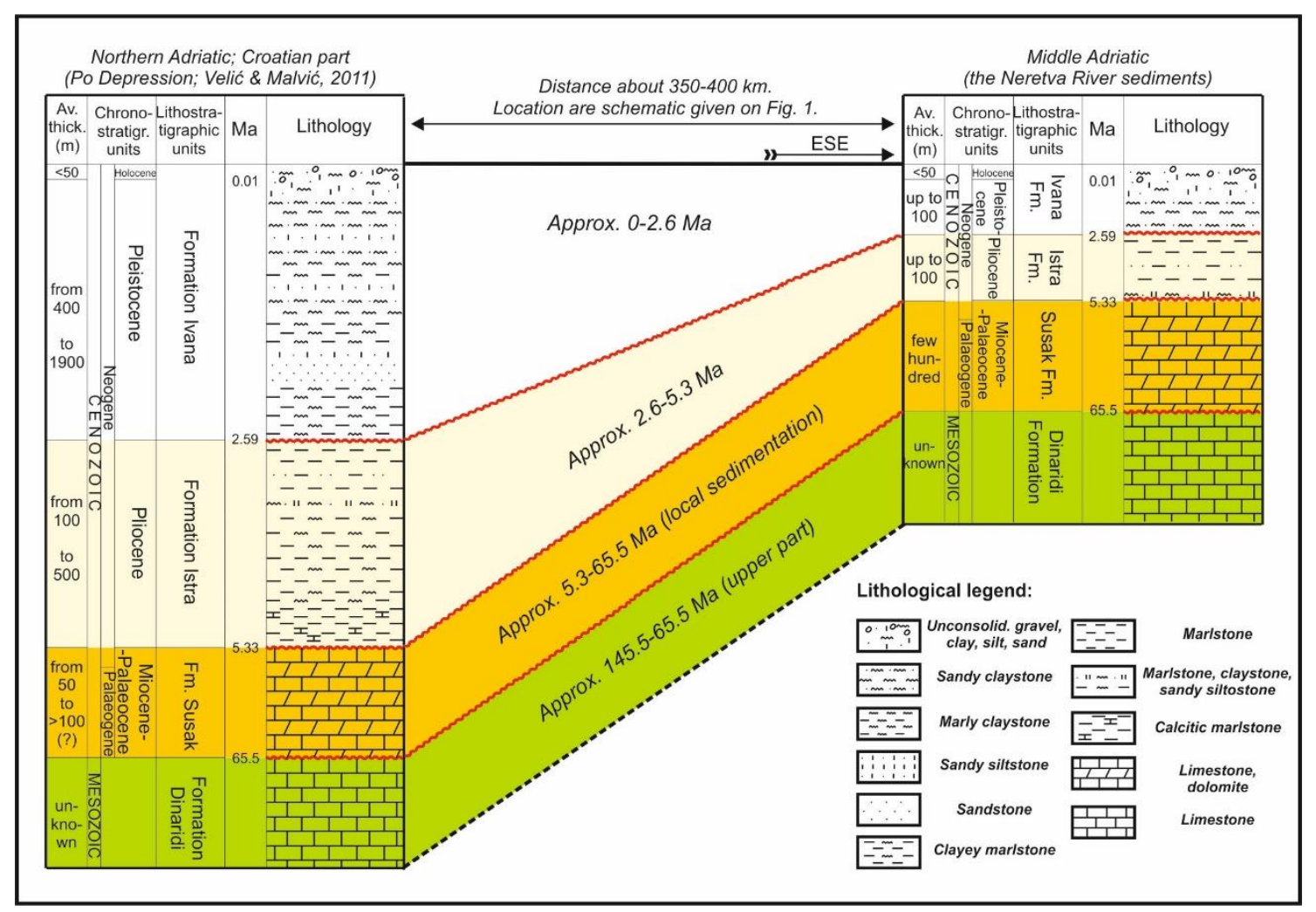

Figure 3: Example of lithostratigraphic formation thicknesses comparison in Croatian's Northern Adriatic and Neretva river deposits in the Middle Adriatic (Velić \& Malvić, 2011; Balić \& Malvić, 2013)

Using the North American Stratigraphical Code, four megasequences have been identified: (i) a pre-platform succession ranging in age from Late Carboniferous (Middle Pennsylvanian: Moscovian) to Early Jurassic (Early Toarcian; Brušane and Baške Ostarije Formations) ; (ii) an Early Jurassic to Late Cretaceous platform megasequence (Mali Alan Formation) ; (iii) a Paleogene to Neogene post-platform megasequence (Raša Formation) ; and (iv) a Neogene to Quaternary (Pliocene to Holocene) megasequence (Istra and Ivana Formations) (Velić et al., 2015). However, Pliocene, Pleistocene and Holocene sediments cover the whole area and are very thick. These sediments consist of marlstones, clays, siltstones, silts, sandstones and sands. Lithostratigraphic units on Croatian and Italian sides have different names, provided that the Italian classification is more detailed, mostly because of different development and bigger Pliocene-Pleistocene sedimentation environment dynamics.

Based on the suggested nomenclature for the Croatian part, Malvić et al. (in review) have presented the results of the research for establishing new members and formations in the Croatian offshore in Pliocene, Pleistocene and Holocene. Inside these areas are the Po and Neretva Rivers' deposits. Through history, on both depressions, six ice-ages have affected them in a way of lowering bathymetry, especially in the Northern Adriatic during Quaternary. In the Croatian Po Depression, three new lithostratigraphic members have been defined within the existing Ivana Formation - Anamarija, Katarina and Izabela, based on the data from Marić Đureković (2011). Further south, in the Middle Dalmatia shallow offshore, the new Neretva Channel Formation has been named. This is divided into the Neretva Sand (or sometimes its lateral equivalent) and the Quaternary Mali Ston Bay Member. No typical Pliocene lithotype has yet been recognised.

\section{Algorithm and program in «R» for defining lithostratigraphic units}

In this paper, the primary purpose of the program has been defining lithostratigraphic units using the method of comparing and analysing porosity data of a vertical of a lithological unit. The type of a lithological unit is defined due to the distribution of a variable. As a null hypothesis, the existence of a normal distribution has been validated. If it is not a normal distribution, conclusions of the type of the lithological unit are based on the 
skewness of the distribution to the left or right. For example, if the distribution is skewed to the right, the peak of the curve is moved to the left, the lithological unit is marlstone. On contrary, if the distribution is skewed to the right, the lithological unit is sandstone. And eventually, with skewness close to o the unit could be a mixed but recognisable "member".

\subsection{The algorithm and source code for defining lithostratigraphic units}

The program can be applied to any lithological unit that has 15 or more measurements on the vertical. For graphic display of the analysis of the results, "R" package "ggplotz" has been used, and for the statistical test of the asymmetry of the distribution, the "moments" package has been used. The algorithm flow chart (Figure 4) for the definition of lithostratigraphic units is used for writing the source code. An example of graphic results is given as histograms in the following text.

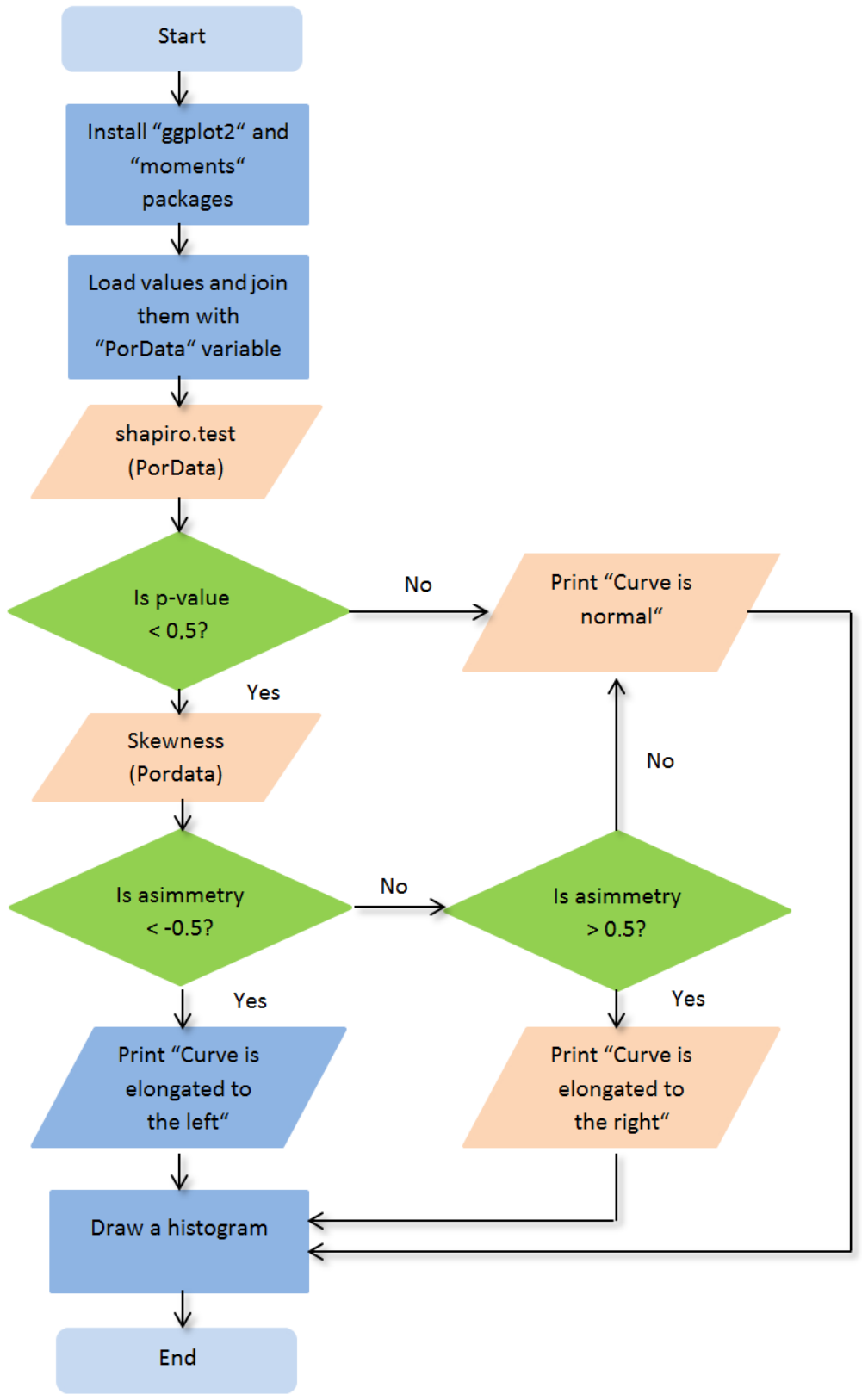

Figure 4: Algorithm flow chart for the definition of lithostratigraphic units 


\subsection{Original source code in «R»}

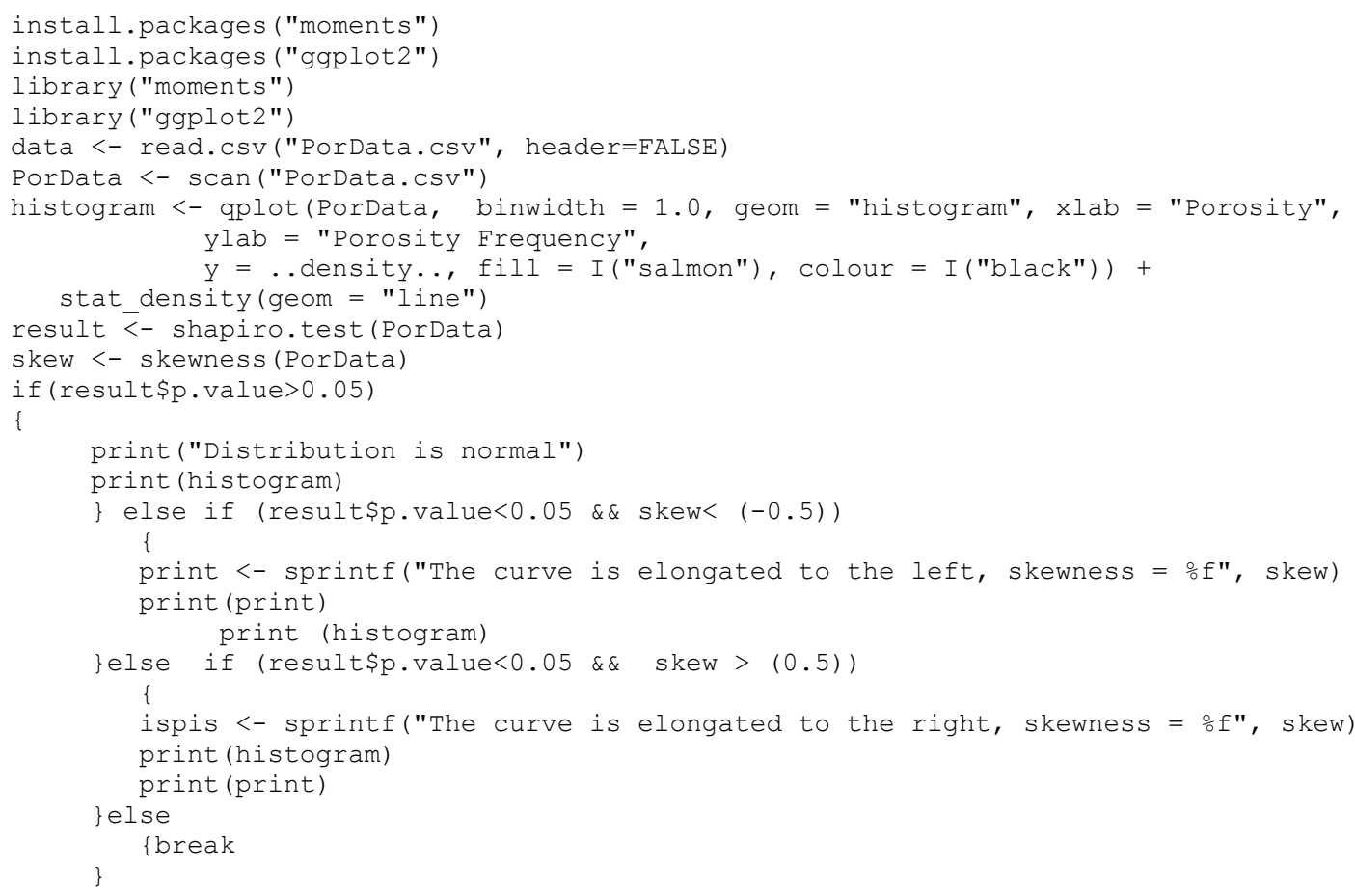

The hypothesis test is made upon the porosity data and the result is assigned to the variable "result". The test is made using the Shapiro-Wilk method (Shapiro \& Wilk, 1965). The Shapiro-Wilk test validates the nullhypothesis, which assumes the existence of normal data distribution. Mathematically, the equation is presented in (4-1):

$W=\frac{\left(\Sigma_{i=1}^{n} a_{i} x_{(i)}\right)^{2}}{\sum_{i=1}^{n}\left(x_{i}-\bar{x}\right)^{2}}$

Where:

$W$ - test statistic;

$x(i)$ - i-th order statistic;

$\bar{x}=\left(x_{1}+\cdots+x_{n}\right) / n-$ sample mean; $\mathrm{a}_{\mathrm{i}}-$ constant.

The null-hypothesis for this test is "the data has normal distribution". If the p-value is less than 0.05 , then the null-hypothesis is rejected. On the contrary, if the p-value is greater than 0.05 , then it is not rejected. The p-value is the estimated probability of rejecting the null-hypothesis. A value of 0.05 means that, in the case that the hypothesis is accepted, the statement will be true in $95 \%$ of cases (vice versa).

In the code, the program's response to the result of the normality test is defined and the asymmetry test (skewness) is performed in the case that $\mathrm{p}<0.05$ (Papoulis \& Pillai, 2002). The skewness test shows to which side the distribution curve is elongated. If the skewness value is less than 0.5 , the curve is elongated to the left, and if it is greater than 0.5 , then the curve is elongated to the right. Finally, the interpretation of the elongation to the left defines the sandstone lithological unit, which means that the majority of the porosity values have higher values, and the elongation to the right means that the lithological unit is marlstone, because of the smaller values of porosity in which the distribution peak is positioned.

In Figure 5, the graphic result of data analysis is shown (see also Table 1). The porosity data is from a vertical of a lithological unit from wellbore A from the Šandrovac Field, collected in Malvić (2003). The algorithm testing 
on the data was successful, and the code alone did correct calculating, graphic results of the data distribution and the Shapiro-Wilk test. In the case of the Šandrovac Field, it is known that the sandstone members are relatively clean, and the null-hypothesis which suggests the existence of normal distribution should have been confirmed. Most of the sandstones are vertically petrophysically very homogenous, but it contains small interval changes of porosity values. They fall in the parts near the top and bottom, where it gradually changes into impermeable lithofacies. Also, the biggest values are commonly in the middle parts of such sandstones, because that is where the biggest detritus is deposited, which means that these parts are deposited in the energetically most powerful environments.

Using the normality test, the following values have been gained: $\mathrm{W}=0.9871$ and $\mathrm{p}=0.85$ and using skewness 0.1749 Due to a p>0.05 and skewness between -0.5 and 0.5, the distribution can be approximated as normal, i.e. the null-hypothesis has been accepted. Geologically, it has been confirmed as a clean member, i.e. sandstone.

Table 1: Input test sample values from wellbore A

\begin{tabular}{rrrrrr}
\hline \multicolumn{1}{r}{ Porosity (\%) } & Depth $(\mathrm{m})$ & \multicolumn{1}{l}{ Porosity (\%) } & Depth $(\mathrm{m})$ & Porosity (\%) & Depth (m) \\
\hline 21.30 & 797.70 & 23.90 & 804.10 & 29.30 & 810.50 \\
19.20 & 798.34 & 17.70 & 804.74 & 24.20 & 811.14 \\
26.20 & 798.98 & 28.70 & 805.38 & 16.80 & 811.78 \\
24.50 & 799.62 & 28.10 & 806.02 & 20.00 & 812.42 \\
22.50 & 800.26 & 26.10 & 806.66 & 22.90 & 813.70 \\
21.00 & 800.90 & 18.20 & 807.30 & & \\
18.90 & 801.54 & 21.50 & 807.94 & & \\
15.40 & 802.18 & 21.70 & 808.58 & & \\
22.70 & 802.82 & 26.30 & 809.22 & & \\
31.40 & 803.46 & 30.30 & 809.86 & &
\end{tabular}

Although the test sample is not a part of the Adriatic Carbonate platform, which lithostratigraphic units are the main subject of the research shown in this paper, the algorithm and the code can be used without problems in those lithological units as well. In that case, it would be necessary to (a) analyse the unit with enough data on the vertical, (b) make the test sample publically available and published. 


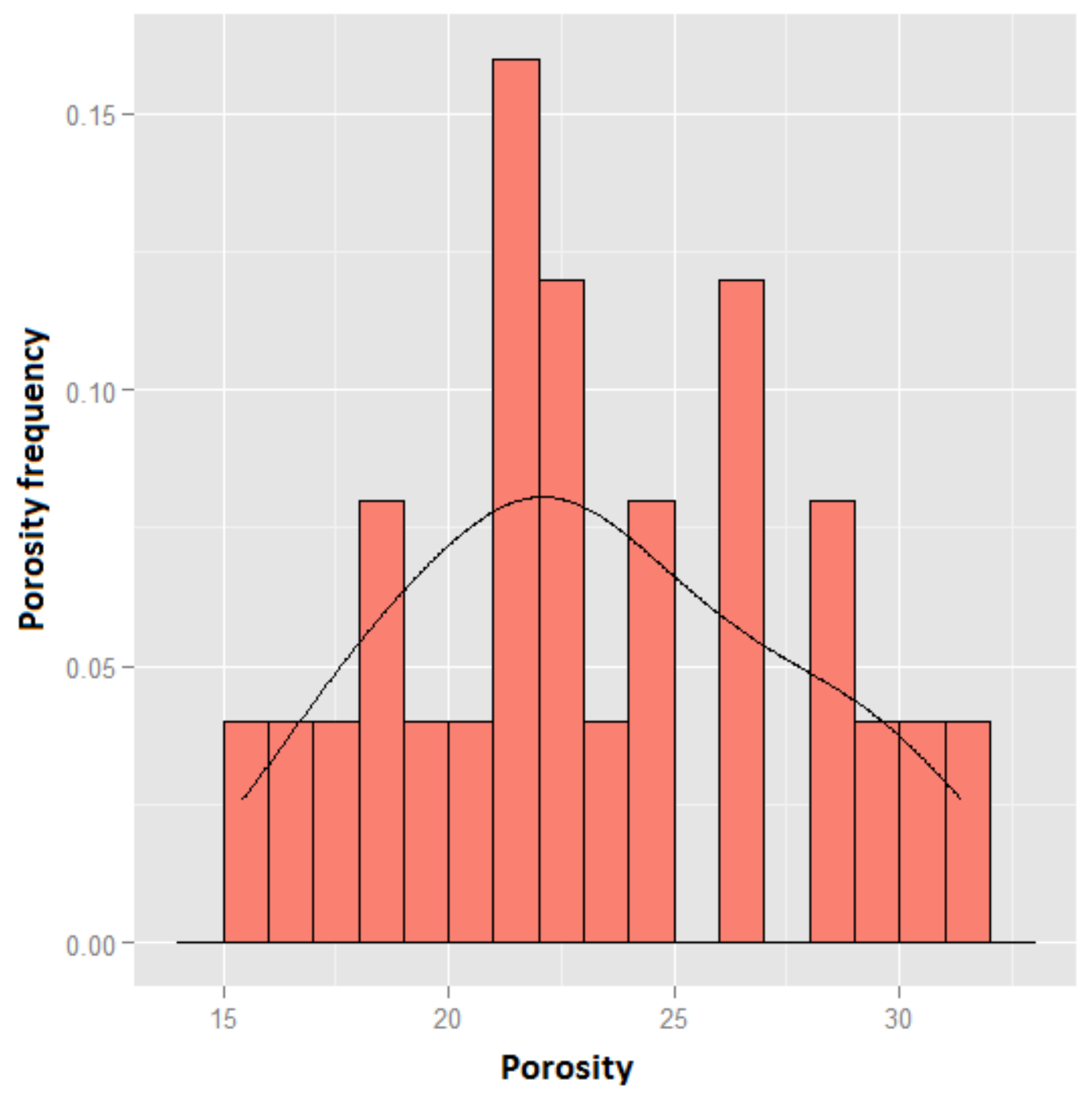

Figure 5: Histogram with frequencies, porosity values and the distribution curve from data from wellbore A, the Šandrovac Field

The results of the test and the program in the case of analysing marlstone, or a lithostratigraphic unit in which distribution is not normal, but the distribution curve is elongated to the right with the porosity value ranging similarly to the former example (15-32\%), but with additional classes with smaller values due to the average characteristics of the lithology is presented in Figure 6.

In this test sample (see Table 2 ) there were 25 porosity values which ranged from 3.60 to 29.30 . Using the Shapiro-Wilk test, values $\mathrm{W}=0.7208$ and $\mathrm{p}=0.00$ have been found. Skewness was 1.5775 . The $\mathrm{p}$-value in this case was smaller than 0.05 , and skewness was bigger than 0.5 . The results gave a distribution curve elongated into right, which shows departure from normal distribution. Lithologically, it is interpreted as marlstone, an impermeable lithofacies. 
Table 2: Input test sample values of a lithological unit with normal distribution

\begin{tabular}{rrrrrr}
\hline \multicolumn{1}{r}{ Porosity (\%) } & \multicolumn{1}{c}{ Depth $(\mathrm{m})$} & Porosity (\%) & \multicolumn{1}{c}{ Depth (m) } & Porosity (\%) & Depth (m) \\
\hline 4.00 & 780.70 & 3.70 & 787.10 & 29.30 & 793.50 \\
8.50 & 781.34 & 4.90 & 787.74 & 24.20 & 794.14 \\
8.30 & 781.98 & 6.40 & 788.38 & 16.80 & 795.78 \\
4.30 & 782.62 & 4.80 & 789.02 & 20.00 & 796.42 \\
4.10 & 783.26 & 5.60 & 789.66 & 22.90 & 797.06 \\
5.00 & 783.90 & 5.40 & 790.30 & & \\
6.10 & 784.54 & 8.70 & 790.94 & & \\
8.40 & 785.18 & 6.30 & 791.58 & & \\
9.00 & 785.82 & 4.20 & 792.22 & & \\
3.60 & 786.46 & 5.50 & 792.86 & &
\end{tabular}

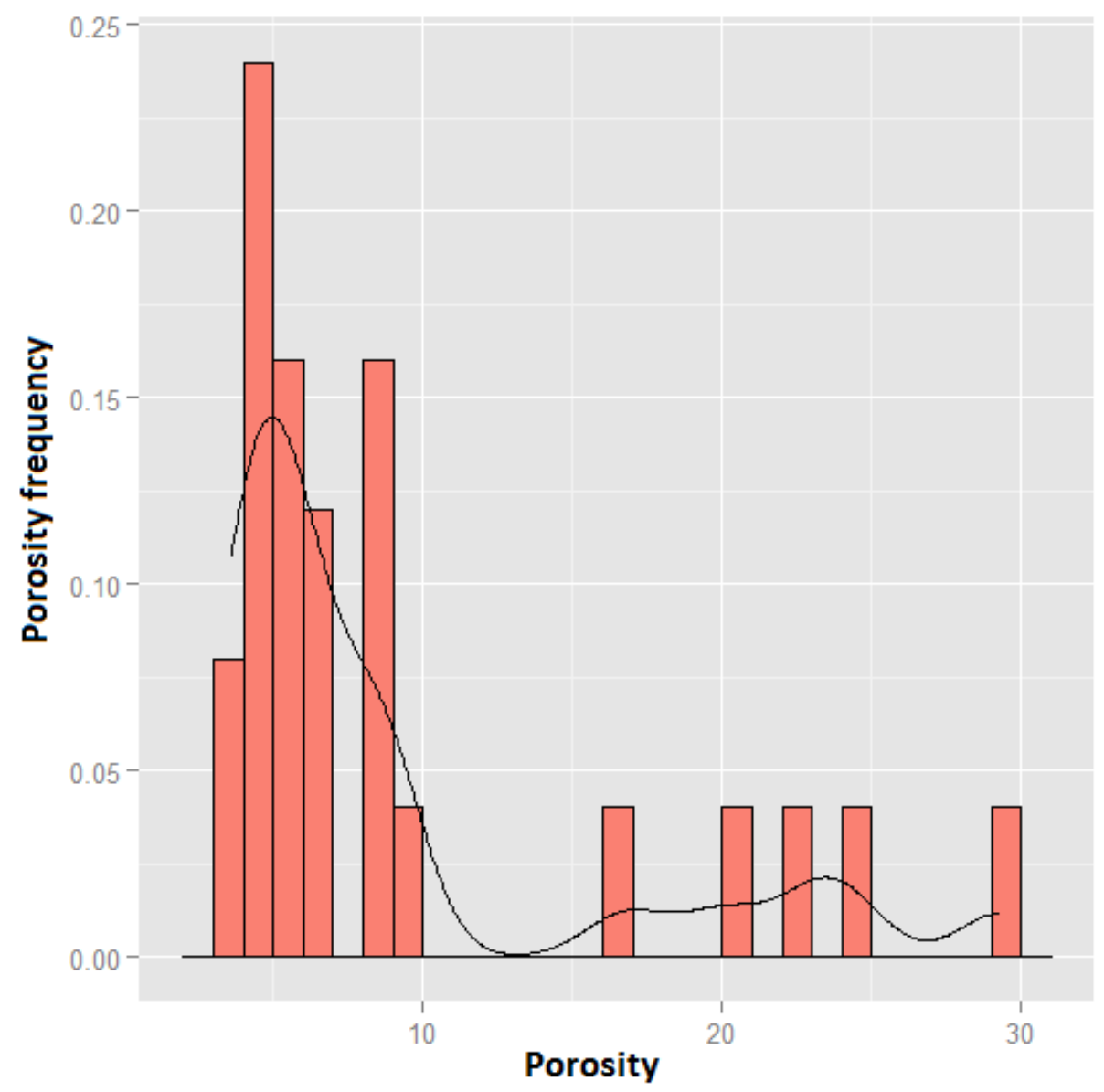

Figure 6: Histogram with frequencies, porosity values and the distribution curve based on the porosity test sample from impermeable lithofacies (marlstone) 


\section{Conclusion}

Numerous hydrocarbon reservoirs, mainly gas saturated, have been discovered in the Po Depression, thus the definition of the deposits following the norms of proper lithostratigraphic nomenclature is necessary. Recently, no detailed lithostratigraphic division has existed in the Croatian part of the Adriatic offshore. For example, on the Italian side Pliocene, Pleistocene and Holocene Po Depression deposits have been defined in twelve formations, while on the Croatian side, only the Susak Formation existed. Today, after additional research, the Susak Formation is replaced with the Raša Formation, including post-platform deposits along the Croatian coast and Dinarides. Moreover, Istra and Ivana Formations are divided into the new Anamarija, Katarina and Izabela Members as a part of the Ivana Formation.

A similar process is successfully applied in the palaeo of the Neretva River, especially Quaternary deposits. Lithologically, several different units exist, so the definition of formations and members following the lithostratigraphic nomenclature is suggested. As a result, the Neretva Channel Formation, with the Neretva Sands and the Mali Ston Bay member are defined.

The definition of lithostratigraphic units is often a descriptive task, based on the observation of outcrops, cores or e-logs. However, when interpreted data is available, it can be quantified and automatized using a sufficient number of measured rock properties (especially porosity). Therefore, the program and algorithm for the computerized definition of members or any other lithostratigraphic unit has been given. The tested samples have confirmed algorithm usefulness in the heterogeneous alternation of clastic units, such as sandstones and marlstones. The test is based on testing the null-hypothesis on the normal distribution of porosity in (assumed) sandstone members. If the null-hypothesis is accepted, the unit is named as "name of the type locality". If the porosity value range is extended to smaller values (usually under $10 \%$ ) and the null-hypothesis is rejected, an impermeable member is defined and can be easily named as "name of the type locality" marlstone. The third case of a heterogeneous lithostratigraphic unit (a member) can be easily indirectly defined by testing several porosity test samples from an identical unit measured on different localities. If the results are ambiguous, i.e. on some localities the null-hypothesis is accepted and on some rejected, it is a heterogeneous unit which could be named "name of the type locality" member.

\section{References}

1. Balić, D., Malvić T. (2013): Pliocene-Quaternary stratigraphy and sedimentation at the Neretva River Mouth, on the Croatian Adriatic Coast. Geological Quarterly, 57, 2, 233-242.

2. Colantoni, P., Gallignani, P., Lenaz, R. (1979): Late Pleistocene and Holocene evolution of the North Adriatic continental shelf (Italy). Marine Geology, 33, M41-M50.

3. Đureković, M., Krpan, M., Pontiggia, M., Ruvo, L., Savino, R., Volpi, B. (1998): Geological modelling and petrophysical characterisation of turbiditic reservoirs of the Ivana gas field-R. Croatia. Nafta, 49, 7-8, 241-258.

4. Fairbanks, F. G. (1989): A 17 ooo years glacio-eustatic sea level record: influence on glacial melting rates on the Younger Drayes event and deep-ocean circulation. Nature, 342, 637-642.

5. Malvić, T. (2003): Naftnogeološki odnosi i vjerojatnost pronalaska novih zaliha ugljikovodika u bjelovarskoj uleknini (OilGeological Relations and Probability of Discovering New Hydrocarbon Reserves in the Bjelovar Sag). Doctoral dissertation, Faculty of Mining, Geology and Petroleum Engineering, Zagreb University, 123 p., Zagreb.

6. Malvić, T., Đureković, M., Šikonja, Ž., Čogelja, Z., Ilijaš, T., Kruljac, I. (2011): Exploration and Production Activities in northern Adriatic Sea (Croatia), successful joint venture INA (Croatia) and ENI (Italy), Nafta: exploration, production, processing, petrochemistry (oo27-755X) 62, 9-10, 287-296.

7. Malvić, T., Velić, J., Cvetković, M., Vekić, M., Šapina, M. (2015): Definition of new Pliocene, Pleistocene and Holocene lithostratigraphic units in the Croatian Southern Adriatic Sea (shallow offshore) (in review, journal "Geoadria”).

8. Marić Đureković, Ž. (2011): Litofacijesne i stratigrafske značajke pleistocenskih naslaga podmorja sjevernoga Jadrana na temelju visokorazlučivih karotažnih mjerenja (Lithofacies and stratigraphy of Pleistocene deposits in North Adriatic Offshore by using high-resolution well logs). Doctoral dissertation, Faculty of Mining, Geology and Petroleum Engineering, Zagreb University, 167 p., Zagreb.

9. North American Commision On Stratigraphic Nomenclature (2005): North American Stratigraphic Code, AAPG Bulletin, 89, 11, 1567-1570.

10. Papoulis, A., Pillai, S. U. (2002): Probability, Random Variables and Stochastic Processes. Fourth Edition, McGraw-Hill, New York, 146-147.

11. Prelogović, E., Kranjec, V. (1983): Geološki razvitak područja Jadranskog mora (Geological development of the Adriatic sea area). Pomorski zbornik, 21, 387-405.

The Mining-Geology-Petroleum Engineering Bulletin, 2015, pp. 13-24 (C) The Author(s), DOI.: 10.17794/rgn.2015.2.4 
12. Shapiro, S.S., Wilk, M.B. (1965): An analysis of variance test for normality (complete samples). Biometrika 52, 3-4, 591-611. 13. Spaić, V. (2012): Nafto-plinonosnost i strukturni elementi jadranskih otoka i poluotoka (vanjski Dinaridi) s posebnim osvrtom na arhidritno-karbonatni kompleks mezozoika i dijapirski pojas (Oil and gas bearingness and structural elements of Adriatic islands and peninsulas (Outer Dinarides) with special review of anhydrite - carbonate Mesozoic complex and diapiric belt). Nafta, 63, 1-2, 38-40.

14. Stanley, D.I. (1995): A global sea level curve for the late Quaternary: the impossible dream?. Marine Geology, 125, 1-6.

15. Tišljar, J. (1984): Sedimentološka i litofacijesna interpretacija karbonatno-anhidritnog kompleksa dubokih bušotina Ravni Kotari-3, Dugi Otok-1, Nin-1, Brač-1 i Lastovo-1 (Sedimentological and lithofacies interpretation of the wells RK-1, DO-1, Nin-1, Brač-1 and Lastovo-1 - in Croatian). Unpubl. Study, INA-Naftaplin, Zagreb, 64 p.

16. Tišljar, J., Vlahović, I., Velić, I., Sokač, B. (2002): Carbonate platform megafacies of the Jurassic and Cretaceous deposits of the Karst Dinarides. Geologia Croatica, 55, 2, 139-170.

17. Velić, I., Vlahović, I., Matičec, D. (2002): Depositional sequences and palaeogeography of the Adriatic Carbonate Platform. Mem. Soc. Geol. Ital. 57, 141- 151.

18. Velić, J. (2007): Geologija ležišta nafte i plina (Geology of Oil and Gas Reservoirs). Faculty of Mining, Geology and Petroleum Engineering, Zagreb University, Zagreb, 342 p.

19. Velić, J., Malvić, T. (2011): Taložni uvjeti tijekom pliocena i pleistocena u Sjevernom Jadranu te moguća litostratigrafska raščlamba nastalih stijena (Depositional conditions during Pliocene and Pleistocene in Northern Adriatic and possible lithostratigraphic division of these rocks). Nafta, 62, 1-2, 25-38.

20. Velić, J., Malvić, T., Cvetković, M., Velić, I. (2015): Stratigraphy and petroleum geology of the Croatian part of the Adriatic Basin, Journal of petroleum geology. (o141-6421) 38, 3; 281-300.

21. Vlahović, I., Tišljar, J., Velić, I., Matičec, D. (2005): Evolution of the Adriatic Carbonate Platform: Palaeogeography, main events and depositional dynamics. Palaeogeography, Palaeoclimatology, Palaeoecology, 220, 3-4, 333-360.

\section{Sažetak (abstract in Croatian)}

\section{NOVE LITOSTRATIGRAFSKE JEDINICE HRVATSKOG PRIOBALJA I NJIHOVA ODREDBA U PROGRAMSKOM JEZIKU «R»}

Nove litostratigrafske jedinice na hrvatskoj strani Jadrana su nedavno predložene i usvojene, i trenutno su u uporabi, poglavito u pleistocensko-holocenskom nizu. Tako su u Sjevernom Jadranu prvo uvedene dvije nove formacije (Istra i Ivana), a zatim imenovana tri nova litostratigrafska člana unutar formacije Ivana, te predložena promjena naziva formacije Susak. Nadalje, u plitkom odobalju Južne Dalmacije, tj. paleo taložinama rijeke Neretve, imenovana je formacija Neretvanski kanal koja je podijeljena u članove pijesci Neretva i član Malostonski zaljev. Kako je definicija litostratigrafskih jedinica često opisni zadatak, u ovome radu je pomoću algoritma i programskog koda izrađenog u programu za statističku obradu podataka „ $\mathrm{R}^{\text {“ omogućeno }}$ pojednostavljenje tog zadatka na temelju dovoljnog broja izmjerenih vrijednosti šupljikavosti po okomici stijene ili taložne sekvencije. Algoritam izravno određuje način testiranja hipoteza o normalnosti razdiobe šupljikavosti, a programski kod to praktično numerički i grafički rješava. Ispitivanje se izvodi Shapiro-Wilkovim testom. Ovisno o rezultatima testiranja nulte hipoteze (normalna razdioba mjerenih podataka) lako je ocijeniti radi li se o homogenoj, propusnoj ili nepropusnoj, ili heterogenoj litostratigrafskoj jedinici, koja se uvijek može razlikovati od krovine i podine. Na temelju rješenja, te poznavanja zemljopisnog mjesta gdje su reprezentativni podatci uzeti, jedinicu je lako imenovati prema pravilima litostratigrafske nomenklature.

\section{Ključne riječi}

Jadran, kenozoik, litostratigrafija, nulta hipoteza, Shapiro-Wilkov test. 